
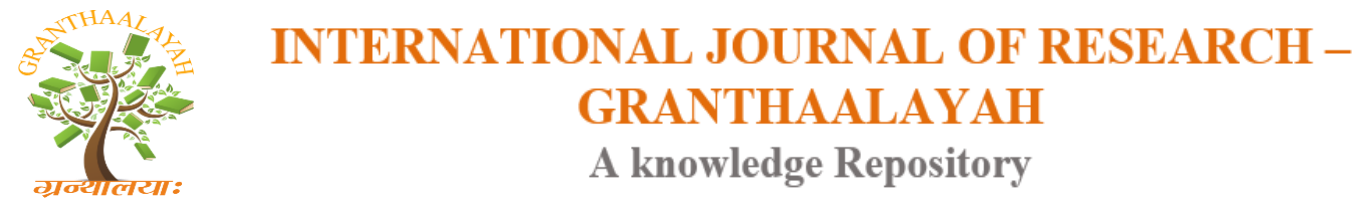

Science

\title{
STUDY OF NATURAL DYE-YIELDING PLANTS WITH ITS MEDICINAL VALUE IN DISTRICT RAJGARH (M.P.)
}

\author{
Ajra Khan ${ }^{1}$, Shail Bala Sanghi ${ }^{2}$ \\ ${ }^{1,2}$ Department of Botany, Govt. M.L.B. Girls P.G. College, Bhopal, INDIA
}

DOI: https://doi.org/10.29121/granthaalayah.v4.i9.2016.2546

\section{ABSTRACT}

The present paper is based on extensive survey. Collection of ethnobotanical information and natural dye yielding plants Rajgarh District (M.P.). The study reports 15 natural dye yielding plant species belong to 13 families. Along with their botanical name, local name, family, habit, dye yielding plant parts used are mentioned in the paper. Apart from, medicinal uses, it also describes preparation of dyeing stuff. Use of mordant's and specific dye utilization to serve various purposes, including several of the new dye resources.

Keywords:

Natural dyes plants, Mordant's, Colourants, Medicinal uses Rajgarh District (M.P.).

Cite This Article: Ajra Khan, and Shail Bala Sanghi, "STUDY OF NATURAL DYEYIELDING PLANTS WITH ITS MEDICINAL VALUE IN DISTRICT RAJGARH (M.P.)" International Journal of Research - Granthaalayah, Vol. 4, No. 9 (2016): 131-135.

\section{INTRODUCTION}

Rajgarh district of M.P. is unexplored botanically despite the fact that it harbours a rich angiospermic flora.

Rajgarh district was constituted after the formation of Madhya Bharat in May 1948. Prior to this the area of the present district was parcelled out among the state of Rajgarh, Narsinghgarh, Khilchipur, Dewas (Senior) and Dewas (Junior) and Indore.

India has a rich bio-diversity and it is not only one of the worlds twelve mega diversity countries but also one of the eight major centre's of origin and diversification of domesticated taxa, it has approximately 49,000 plant species of which about 17,500 are angiosperms.

The purpose of the present investigation is to study the flora of Rajgarh district in general and to find out prospective species of plants which are the sources of natural in particular dyes. As stated earlier. The natural dyes do not pose any threat to health of users which is not the case 
with synthetic dyes. Moreover the natural dyes are commonly available and because of their availability at cheaper cost there are within the reach of common man.

Rajgarh district lies in the northern part of Malwa plateau and in the east part of M.P. it forms the north western part of Bhopal Commissioners division. Rajgarh district extends between the Latitude ' $23^{\circ} 28^{\prime}$ and $24^{\circ} 18^{\prime}$ ' north and the longitude ' $76^{\circ} 11^{\prime}$ ' and $77^{\circ} 20^{\prime}$ ' east.

The total area of the Rajgarh district is 6,154 sq.km. It is one of the small districts of Madhya Pradesh and situated about 400mtr above the mean sea - level.

It is bounded in the west by Shajapur district in the north by Jhalawad of district Rajasthan in the north east by Guna of M.P. and in the south east Sehore district.

Tha maximum forest cover in the district is of mixed forest which includes Teak (Tectona grandis) Mixed with other species like Saja (Terminalia tomentosa), Arjun (Terminalia arjuna), Amaltas (Cassia fistula), Amla (Emblica officinalis) etc.

The medicinal trees and plants of various kinds are found in abundance in the forest.

The forest of the district belongs to the dry deciduous mixed and shrub types. Mostly their timber value is small. The common species of the forests are Dhow (Anogeisus latifolia), Khair (Acacia catechu), Ber (Zizyphus jujuba), Karondi (Carissa spinarum), Kordhai (Anogeissus pendula), Babul (Acacia arabica), Achar (Buchanania latifolia), Palash (Butea frondosa), Tendu (Diospyros melanoxylon), Neem (Azadirachta indica), Pipal (Ficus religiosa), Jamun (Eugenia jambolana), Sandal (Santalum album)etc.

\section{MATERIAL AND METHODS}

Various plants of the district shall be collected for extracting dyes depending upon the specific part of the plant resource to extract dye from underground root or rhizome, stem or bark, the material is cut into pieces, soaked in water for two to three days and made into paste. The dye is generally prepared by boiling the crushed powder with water but sometimes it is left to steep in cold water after squeezing and filtration, the whole extract is boiled and connects rated by repeated heating subject to specific requirement Alum is generally used as a mordant. Flowers of Butea monosperma yield an orange colored dye. A more permanent colour is produced either by first preparing the cloth with alum and wood ash, or by adding these substances to the dye bath. Mallotus philippinensis yields an orange colour used for dyeing silk and wool. The floral parts and leaves when used for dye are crushed and dissolved. To prepare the annatto dye from Bixa orellana the fruits are collected when nearly ripe, the seeds and pulp are removed from the mature fruit and macerated with water. Thereafter dye are either ground up into an annatto paste, or dried and marketed as annatto seeds. Sometimes when the seeds and pulp are macerated with water. The product is stained through a sieve and the colouring matter which settles out collected and evaporated by heat and finally dried in the sun. Mordant result into variation in dye colour, even same dye can produce different colours several of the vegetable dyes are used as mordants and usage of mixture of dyestuff is a common practice. Light solution of organic manure, cream of tartar, curd water ash of wood or bark, rock salt, lemon juice , lime water are common 
mordants used by the locals. Relevant literature 1-15 has been consulted for the preparation of this manuscript.

Extract from dye yielding parts of several plants such as species of Achyranthus, Adhtoda, Anogesessus, Cinnamomum, Rhododendron, Solanum, Tamarindus, Tectona etc are occasionally used as mordants.

Table 1: Important Natural dye yielding plants with its medicinal value

\begin{tabular}{|c|c|c|c|c|c|}
\hline S.N. & $\begin{array}{l}\text { Botanical name/ } \\
\text { Local name } \\
\text { / Family }\end{array}$ & Habbit & $\begin{array}{l}\text { Dye } \\
\text { yielding } \\
\text { plant part }\end{array}$ & $\begin{array}{c}\text { Dye } \\
\text { produced }\end{array}$ & Medicinal uses \\
\hline 1. & $\begin{array}{l}\text { Acacia catechu } \\
\text { Linn./Katha/ } \\
\text { Mimosacae }\end{array}$ & Tree & Bark & $\begin{array}{c}\text { Brown/ } \\
\text { Black }\end{array}$ & $\begin{array}{l}\text { Kheersal is used medicinally for } \\
\text { sore throat and cough. }\end{array}$ \\
\hline 2. & $\begin{array}{l}\text { Adathoda vasica } \\
\text { Nees./Adusa/ } \\
\text { Acanthaceae }\end{array}$ & Herb & Leaf & Yellow & Used in bronchial infection. \\
\hline 3. & $\begin{array}{l}\text { Aegle marmelos } \\
\text { L./Bel/ Rutaceae }\end{array}$ & Tree & Fruit rind & Yellow & $\begin{array}{l}\text { Unripe or half ripe fruit is } \\
\text { astringent used as digestive and for } \\
\text { curing stomach ache, diarrhea. }\end{array}$ \\
\hline 4. & $\begin{array}{l}\text { Aloe barbadensts } \\
\text { L./ Aloe/ Liliaceae }\end{array}$ & Herb & $\begin{array}{l}\text { Whole } \\
\text { plant }\end{array}$ & Red & $\begin{array}{l}\text { Fresh juice of leaves is cathartic } \\
\text { and refrigerant used in liver and } \\
\text { spleen ailment and for eye } \\
\text { infection. }\end{array}$ \\
\hline 5. & $\begin{array}{l}\text { Azadirachta } \\
\text { indica Juss./ } \\
\text { Neem/ Meliaceae } \\
\end{array}$ & Tree & Bark & Brown & $\begin{array}{l}\text { Skin disorders, leaves considered as } \\
\text { antiseptic. }\end{array}$ \\
\hline 6. & $\begin{array}{l}\text { Barleria prionitis } \\
\text { L. /Cutsaeya/ } \\
\text { Acanthaceae }\end{array}$ & & Flower & Yellow & $\begin{array}{l}\text { Juice of leaves given with honey in } \\
\text { catarrhal infections of children. }\end{array}$ \\
\hline 7. & $\begin{array}{l}\text { Butea } \\
\text { monosperma } \\
\text { (Lam.)/ Palas/ } \\
\text { Paplionaceae }\end{array}$ & Tree & Flower & $\begin{array}{l}\text { Yellow/ } \\
\text { Orange }\end{array}$ & $\begin{array}{l}\text { Bark astringent, used for piles } \\
\text { tumour and menstrual disorders. }\end{array}$ \\
\hline 8. & $\begin{array}{l}\text { Cassia fistula L. / } \\
\text { Amaltas/ } \\
\text { Leguminaceae }\end{array}$ & Tree & Bark & Brown & $\begin{array}{l}\text { Bark astringent, used for piles } \\
\text { tumour, menstrual disorders used } \\
\text { for rheumatism. }\end{array}$ \\
\hline 9. & $\begin{array}{l}\text { Emblica officinalis } \\
\text { Gaertn/ Awla/ } \\
\text { Euphorbiaceae }\end{array}$ & Tree & $\begin{array}{l}\text { Fruits/ } \\
\text { Bark }\end{array}$ & $\begin{array}{l}\text { B blue/ } \\
\text { Black }\end{array}$ & $\begin{array}{l}\text { Fruit used for Diarrhea and } \\
\text { dysentery liver diseases and cough. }\end{array}$ \\
\hline 10. & $\begin{array}{l}\text { Euginia } \\
\text { jambolana L. } \\
\text { Jamun/ Myrtaceae }\end{array}$ & Tree & $\begin{array}{l}\text { Bark/ } \\
\text { Leaf }\end{array}$ & Red & $\begin{array}{l}\text { Decoction of bark and seeds used in } \\
\text { diabetes. }\end{array}$ \\
\hline 11. & Hibiscus rosa- & Tree & Flower & Red & Swelling pain leaves of hibiscus \\
\hline
\end{tabular}




\begin{tabular}{|l|l|l|l|l|l|}
\hline & $\begin{array}{l}\text { sinensis L. / } \\
\text { Gudhal/ } \\
\text { Malvaceae }\end{array}$ & & & $\begin{array}{l}\text { rosa are crushed and fail in waters } \\
\text { mad paste. }\end{array}$ \\
\hline 12. & $\begin{array}{l}\text { Jatropa curcas L./ } \\
\text { Ratanjot/ } \\
\text { Euphorbiace }\end{array}$ & Red & $\begin{array}{l}\text { Bark/ } \\
\text { Leaf } \\
\text { L. / Heena / } \\
\text { Lytheraceae }\end{array}$ & Blue & $\begin{array}{l}\text { Used in sciatica, dropsy and } \\
\text { paralysis externally for skin } \\
\text { disorders and rheumatism. }\end{array}$ \\
\hline 14. & $\begin{array}{l}\text { Tagetes erecta } \\
\text { L./Genda/ Herb } \\
\text { Asteraceae }\end{array}$ & Flower & Yellow & $\begin{array}{l}\text { Used in skin infections. } \\
\text { disorder. }\end{array}$ \\
\hline 15. & $\begin{array}{l}\text { Terminalia } \\
\text { belirica } \\
\text { (Gaertn)/Bahera/ } \\
\text { Combrataceae }\end{array}$ & Tree & Fruit & Blue & $\begin{array}{l}\text { The fruits have antibacterial } \\
\text { properties and useful in many } \\
\text { diseases. }\end{array}$ \\
\hline
\end{tabular}

\section{RESULT AND DISCUSSION}

Prior to the discovery of synthetic dyes. The natural dyes had been in continuous exploration and excessive utilization.

Natural dyes are environment friendly for instance Turmeric the brightest of all naturally occurring yellow dyes is a powerful antiseptic which revitalizes the skin, while indigo gives a cooling sensation. This discovery led to an advance domain of synthetic dyes replacing the natural dyes. Thus for the last many years synthetic dyes dominated however, some of them like Turmeric, Sandal, Heena, Katha, Palash, Amaltas, Bahera, Ratanjot etc. ever remained in demand for their distinct qualities.

Moreover recently plant dyes regain their importance on account of their non-problematic and eco-friendly nature as compared to synthetic dyes.

Some of the synthetic dyes are found to be associated with hazards affecting human life creating skin diseases and pulmonary problems. The environmentalists therefore, started searching the substitute of synthetic items which has lead to the use of more and more natural dyes. Keeping in view the significance of natural dyes, some aspects of the resources from a rich biodiversity district Rajgarh are briefly mentioned hereunder.

\section{CONCLUSION}

Nowadays fortunately, there is increasing awareness among people towards natural products. Rajgarh district in special emphasis on flowering plants (Angiosperms), a field which is still unexplored, it is also expected to find out new dye yielding species of plants. The extraction of these dyes shall also be helpful in generating employment for downtrodden. 
Moreover the dyes shall be available at cheaper cost and therefore within the reach of common men. Due to their nontoxic properties, low pollution and less side effects natural dyes are used in day to day food products. More detailed studies and scientific investigations are needed to assess the real potential and availability of natural dye-yielding resources and for propagation of species in great demand on commercial scale Biotechnological and other modern techniques are required to improve the quality and quantity of dye production.

\section{REFERENCES}

[1] Chandramouli, K.V. (1995). Sources of natural dyes in India. A compendium with regional names PPST foundation. Chennai.

[2] Gulrajani, M.L. (1992). Introduction to natural dyes. Indian Institute of Technology, New Delhi.

[3] Gaur, R.D. (2008) Traditional dye yielding plants of Uttarkhand, India. Natural products Radiance 7(2): 154-165.

[4] Gulrajani, M.L.(2001) Prasent status of natural dyes. India J. Fibre Text Res.Delhi 26 : 191-201.

[5] Kappor, V.P. and Pushpangadan P.(2002) Natural dye based herbal gulal. Nat, prod. Rad 1(2), 8-14.

[6] Mitra R. and Kapoor V.P. (1999) Tannins containing plants part-II History, distribution, Sources and uses, Applhot Abstr (NBRI, Lucknow) 19 (4),279-314.

[7] Sachan, K. and Kapoor V.P. (2004) Eucalyptus bark dye: standardization of extraction and eco-friendly dyeing profiles. Colourage, 51(9):41-44.

[8] Sachan, K. and Kapoor V.P. (2007) optimization of extraction and dyeing conditions for traditional turmeric dye. Indian J. Trad knowledge 6(2): 270-278.

[9] Singh, R. Jain A., Panwan, S, Gupta D and Khare S.K. (2005) Antimicrobial activity of natural dyes. Dyes pigm 66: 99-102.

[10] Singh, R.V. (2001) Colouring plants. An Innovative media to spread the message of conservation. Down to earth 10: 25-27.

[11] Singh V and Singh R.V.(2002) Healthy hues Down to earth 11: 25-31.

[12] Siva R. and K.V. Krishnamurthy (2005) Isozyme diversity on Cassia auriculata Afr J. Biotechnol 4: 772-775.

[13] Venkat P.S. (2000) Chemistry of natural dyes. Resonance, 5: 73-80. 